\title{
COULD GASTRIC HISTOLOGY BE A USEFUL MARKER FOR MAKING DECISION ON Helicobacter pylori ERADICATION THERAPY IN PATIENTS WITH DYSPEPSIA?
}

\author{
Severino Marcos Borba de ARRUDA ${ }^{1}$, Nora Manoukian FORONES ${ }^{2}$, Norma Thomé JUCÁ ${ }^{3}$ and \\ Kátia Simone Cezário de BARROS1
}

\begin{abstract}
Context - It still remains an open debate whether Helicobacter pylori eradication is beneficial or not for the improvement of symptoms in functional dyspepsia. Differences in geographic distribution, the worldwide H. pylori genetic variability and the fact that the outcome of infection is strongly related to the virulence of the infecting strain are factors that might be driving ongoing controversies. Objective - To study the correlation between gastric histology and H. pylori serology status in patients with dyspepsia. Methods - This is a cross-sectional study where 40 consecutive dyspeptic patients ( 28 women and 12 men, mean age 48.5 years) with endoscopically normal stomachs were selected from the endoscopy unit at a university hospital in Recife, PE, Northeast of Brazil, between March 1998 and July 1999. Patients underwent gastric mucosal biopsy and serological tests (anti-Hp and anti-CagA antibodies). Gastric biopsies were examined using H-E and Giemsa stains and gastritis was classified and graded (mild, moderate or severe) according to "the updated Sydney System - Houston, 1994". Results - Among 40 patients with dyspepsia the gastric histology revealed that about $1 / 4$ had moderate $(25 \%)$ or severe $(2.5 \%)$ gastritis. This subgroup of patients also had a greater positive frequency of anti-Hp $(100 \%$ vs $41 \% ; P=0.0005)$ and anti-CagA $(91 \%$ vs $58 \% ; P=0.09)$ antibodies when compared with those with normal histology $(27.5 \%)$ or mild gastritis $(45 \%)$. Conclusion - Since upper gastrointestinal endoscopy is part of the functional dyspepsia investigation and serology for anti-CagA antibody is not available in daily clinical practice, by biopsying gastric mucosa we would only be able to selectively apply $H$. pylori eradication therapy for those with histology that best correlate with virulent infecting strains (moderate or severe gastritis) - around $1 / 4$ of our study patients with dyspepsia.
\end{abstract}

HEADINGS - Dyspepsia. Helicobacter pylori. Helicobacter infections. Antigens, bacterial. Gastritis.

\section{INTRODUCTION}

Nowadays, the functional gastrointestinal disorders (FGIDs) are well conceptualized clinical entities in which there is no organic alteration and the diagnoses follow symptoms-based criteria - The Rome Classification System. They have been interpreted as the clinical expression of the interaction between psychosocial factors and altered gut physiology (motor and/or visceral perception disturbances) via the bi-directional brain-gut axis, having a genetic background and an exposition of environmental factors as the basis of their pathogenesis ${ }^{(8,21)}$.

The most widely used definition for dyspepsia is a recurrent pain or discomfort around midline in the upper abdomen. Once any organic disease causing the dyspeptic symptoms has been ruled out a patient is considered to be suffering from functional dyspepsia (FD). As defined by the Rome III criteria (2006) symptoms in
FD must have began at least 6 months before diagnosis and be active for the last 3 months. Besides abdominal pain or discomfort, the symptom complex may include postprandial fullness, nausea, vomiting, bloating, early satiety, belching and epigastric burning. The Rome III System classifies functional dyspepsia (category B1) into two conditions (subtypes): postprandial distress syndrome (B1a) and epigastric pain syndrome (B1b); these are similar to dysmotility-like and ulcer-like dyspepsia of the former Roma II classification ${ }^{(8,21)}$.

The so-called post-infection FD occurring after acute gastrointestinal infection postulates that inflammation may cause alterations in the enteric nervous system and visceral sensation by modifying signaling in the brain-gut axis. H. pylori-induced inflammation of the gastric mucosa in FD falls into the same logic, suggesting that acute and chronic inflammation seem to play some role in the FD pathogenesis. However, so

\footnotetext{
1 Department of Internal Medicine, Division of Gastroenterology, "Universidade Federal de Pernambuco", Recife, PE, Brazil; ${ }^{2}$ Department of Internal Medicine, Division of Gastroenterology, "Universidade Federal de São Paulo", SP, Brazil; ${ }^{3}$ Department of Anatomopathology, "Universidade Federal de Pernambuco", Recife, Brazil. Correspondence: Dr. Severino Marcos Borba de Arruda - Departamento de Medicina Clínica - UFPE - Av. Prof. Moraes Rego, S/N - Hospital das Clínicas - Cidade Universitária - 50670-901 - Recife, PE, Brazil. Email: smbarruda@uol.com.br
} 
far, FD following acute enteric infection accounts for about $1 / 3$ of FD cases indicating that active inflammation including the one caused by $H$. pylori infection needs to be interpreted and treated on the basis of selected cases ${ }^{(13,22,23)}$. Therefore, maybe the controversy involving the benefit of eradication of $H$. pylori in the treatment of FD is related to the mistake of looking at all patients in the same way.

The pathogenesis underlying the gastric mucosal inflammatory process clearly expresses the relationship to host genetic susceptibility; $H$. pylori infecting strain genotype and other cofactors, such as nutritional and smoking habits. It is well known that $H$. pylori strains are heterogeneous and the outcome of infection is related to their virulence factors. In general, people infected with strains possessing $\mathrm{s} 1 \mathrm{~m} 1 /$ $\mathrm{CagA}+$ genotype have a much greater risk of developing peptic ulcer, atrophic gastritis and gastric cancer, whereas those possessing vacA $\mathrm{s} 2 \mathrm{~m} 2$ genotype tend to have a protective effect concerning these clinical entities ${ }^{(3,4,17,26)}$.

Here we focused on analyzing the correlation between histology (grade of gastritis) and serology for H. pylori infection (including the main $H$. pylori virulence marker: anti-CagA antibody) in a sample of patients with dyspepsia, trying to identify objective histological parameters that could be useful in daily practice when making decisions on $H$. pylori eradication as part of FD treatment.

\section{METHODS}

\section{Subjects}

We studied 40 consecutive adult patients (28 women and 12 men, mean age 48.5 ( \pm 16$) \mathrm{yr}$, range $21-83 \mathrm{yr})$ with dyspeptic symptoms (as defined by TALLEY et al. ${ }^{(24)}$ ) and endoscopically normal stomachs selected from the endoscopy unit of the university hospital at "Universidade Federal de Pernambuco" - UFPE, in Recife, PE (Northeast of Brazil) between March 1998 and July 1999. We excluded patients with any suppressing disease, those aged less than 18 years old, persons previously treated for $H$. pylori or with endoscopic findings of duodenal ulcers and/or erosive esophagitis.

\section{Technical procedures}

Endoscopic procedures were performed by the same endoscopist. In all patients we collected two specimens from the antrum and two from the lower body. At the same time serum samples were stored at $-70^{\circ} \mathrm{C}$ until assayed. The fragments collected were examined at the pathology service (University Hospital-UFPE) by only one pathologist using H-E and Giemsa stains, at which point the occurrence of $H$. pylori were investigated. Gastritis was classified and graded (mild, moderate or severe) according to the updated Sydney System - International Workshop on the Histopathology of Gastritis (Houston, 1994) considering graded variables $(H$. pylori density, polymorphonuclear neutrophil activity, chronic inflammation, glandular atrophy and intestinal metaplasia) and the non-graded variable, lymphoid follicles ${ }^{(7)}$. The presence of $H$. pylori was classified, using Giemsa staining, as positive or negative. Serologic testing was done using ELISA assays for detection of anti-Hp (IgG) and anti-CagA (IgG) antibodies. Each sample was assayed twice for Hp detection. Regarding anti-CagA antibodies, each sample was assayed once using a commercial kit (Oravax. Inc. Cambridge, MA, USA). All tests were run at Stanford University School of Medicine (California, USA).

\section{Study design and statistical analysis}

This is a cross-sectional study where patients with dyspeptic symptoms and normal stomach by endoscopic examination were studied according to serology for $H$. pylori infection and gastric histology. Data was expressed as means \pm standard deviation (SD) and frequency (absolute and percentage values). Comparisons between groups were made using Chi-square with Yates correction if the criteria for correction were met and/or Fisher's exact test by means of $2 \times 2$ tables.

\section{Ethical features}

Participation in the study was voluntary after an explanation of intentions and signing up the informed consent. The protocol was approved by the Research Ethical Committee at UFPE.

\section{RESULTS}

\section{Demographic data}

Table 1 shows data on gender, age and the frequencies of serological tests for $H$. pylori infection. Both groups of men and women are homogeneous according to mean age and the incidences of antibody anti-Hp and anti-CagA. Overall, the frequencies of anti-Hp and anti-CagA antibodies were, respectively: 57\% (23/40) and 74\% (17/23).

\section{Histology and serology}

TABLE 1. Demographic data and frequency of serological test

\begin{tabular}{lcccc}
\hline Gender & Mean age (yr) & $\mathbf{n}(\%)$ & $\begin{array}{c}\text { anti-Hp (+) } \\
\mathbf{n}(\%)\end{array}$ & $\begin{array}{c}\text { anti-CagA (+) } \\
\mathbf{n}(\%)\end{array}$ \\
\hline Female & 48.6 & $28(70)$ & $15(53.5)$ & $11 / 15(73)$ \\
Male & 48.3 & $12(30)$ & $8(66.6)$ & $6 / 8(75)$ \\
Total & 48.5 & $40(100)$ & $23 / 40(57)$ & $17 / 23(74)$ \\
\hline Chi-square w/y & & & $P=0.67$ & $P=0.68$ \\
\hline
\end{tabular}

Table 2 shows data on histology and serology. Among a total of 40 patients, $11(27.5 \%)$ presented mucosal specimens within normal histology, $18(45 \%)$ with minimal alteration classified as mild chronic gastritis, $10(25 \%)$ with moderate chronic gastritis and $1(2.5 \%)$ with atrophic gastritis and intestinal metaplasia $(\mathrm{AG}+\mathrm{IM})$. According to histopathological groups, those with normal histology $(27.5 \%)$ compared with those with any grade of gastritis $(72.5 \%)$ presented the following seropositivity for anti-Hp: $9 \%$ vs 76\% $(P=0.0001)$, and anti-CagA: $0 \%$ vs $77 \%$ antibodies (Figure 1). In the same way, now comparing patients with minimal (normal + mild gastritis) against worse (moderate gastritis + AG/IM) histopathological findings, the correlation between histology and serology showed a marked and significant difference as for anti-Hp seropositivity ( $41 \% \mathrm{vs}$ $100 \% ; P=0.0005$ (Figure 2)), and a trend for significance as for anti-CagA seropositivity ( $58 \%$ vs 91\%; $P=0.09$ (Figure 3)). 
TABLE 2. Correlation between gastric histology and serological tests

\begin{tabular}{|c|c|c|c|}
\hline Histology & n (\%) & anti-Hp (+) & anti-CagA (+) \\
\hline Normal $^{\#}$ & $11(27.5)$ & $1 / 11(9)$ & $0 / 1(0)$ \\
\hline Mild CAG ${ }^{\#}$ & $18(45)$ & $11 / 18(61)$ & $7 / 11(63)$ \\
\hline Moderate $\mathrm{CAG}^{\ddagger}$ & $10(25)$ & $10 / 10(100)$ & $9 / 10(90)$ \\
\hline $\mathrm{Ag}+\mathrm{IM}^{\ddagger}$ & $1(2.5)$ & $1 / 1(100)$ & $1 / 1(100)$ \\
\hline Total & $40(100)$ & $23 / 40(57)$ & $17 / 23(74)$ \\
\hline Fischer's exact test* & & $P=0.0005$ & $P=0.09$ \\
\hline
\end{tabular}

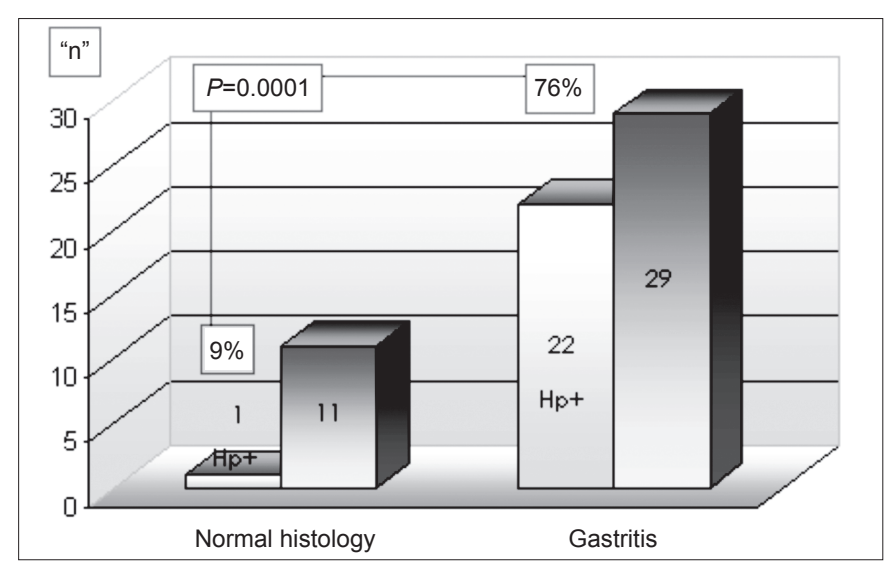

FIGURE 1. Anti- $H p$ seropositivity in normal histology vs gastritis

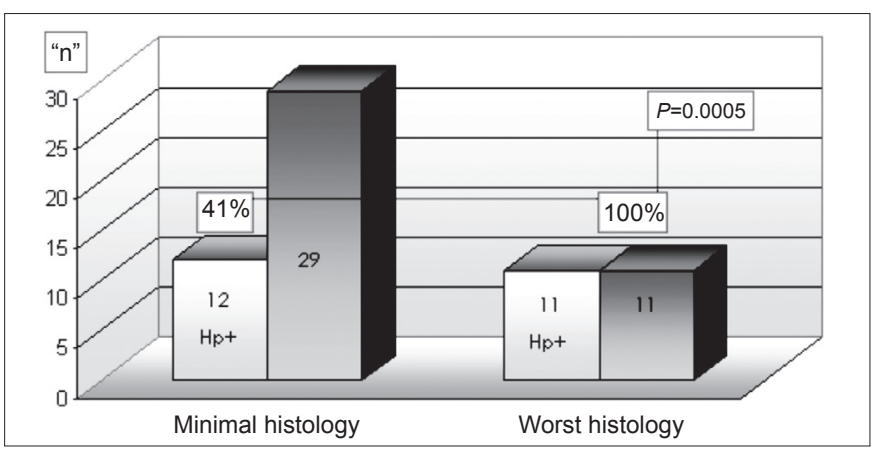

FIGURE 2. Anti-Hp seropositivity in minimal vs worst histopathologic findings

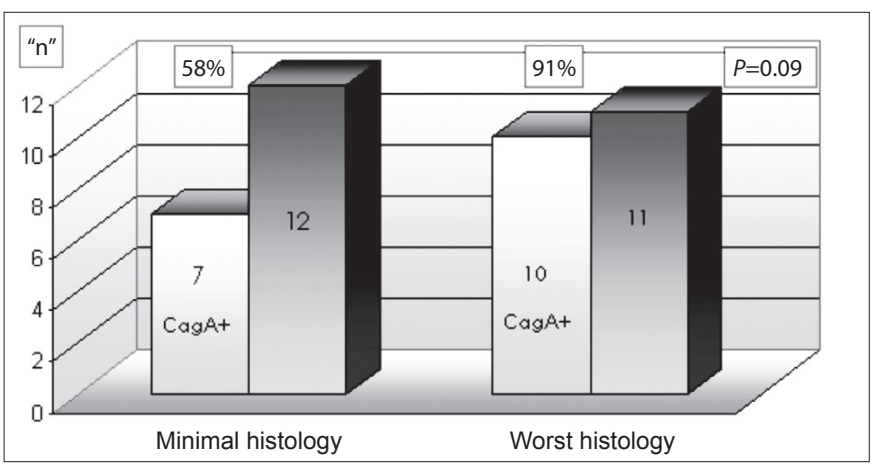

FIGURE 3. Anti-CagA seropositivity in minimal vs worst histology findings

\section{DISCUSSION}

The role of chronic inflammation caused by H. pylori infection in patients with FD remains a controversial issue. Literature reviews, including several meta-analysis studies published over the last 15 years, have showed that less than 4 among 10 patients with FD will experience complete relief from dyspeptic symptoms following successful $H$. pylori

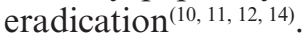

In addition to this controversy there is growing evidence that the decline in the prevalence of $H$. pylori infection in Western developed countries might be associated with the increase in incidences of reflux esophagitis, Barrett's esophagus, and esophageal adenocarcinoma. Therefore, the decision to treat $H$. pylori infection in patients with FD needs to be made considering $H$. pylori as a cofounding factor in the majority of the cases, and that there is also the possibility of breaking the microenvironment equilibrium in the gastric mucosa, which in turn may increase the risk of gastroesophageal reflux associated diseases ${ }^{(1,6,18)}$.

There is consistent evidence that cagA-bearing $H$. pylori strains, which largely used to be associated to vacA s $1 \mathrm{~m} 1$ genotype, induce a more aggressive gastric mucosal inflammatory response as well as gastric epithelial damage altering the local balance between cell proliferation and apoptosis (programmed cell death); there is a strong correlation with this phenomenon and more severe clinical outcomes, such as peptic ulcer, gastric atrophy, intestinal metaplasia, gastric adenocarcinoma, and MALT lymphoma; all of which are consensually accepted as $H$. pylori-treatment indications ${ }^{(2,9,19)}$.

Concerning the relationship between $H$. pylori genetic variation and dyspeptic symptoms, CHING et al..$^{(5)}$ demonstrated that patients with non-ulcer dyspepsia are more likely to be anti-CagA than asymptomatic controls $(55.6 \%$ vs $29 \%$; $P<0.005)$. In the same way, NELSON et al. ${ }^{(16)}$ comparing 435 healthy blood donors and 102 general medicine clinic respondents, found that clinic respondents were more likely to meet the case definition for non-ulcer dyspepsia (34\% vs $13 \%, P<0.001$ ), to be seropositive for $H$. pylori ( $54 \%$ vs $18 \%$, $P<0.001$ ), and to be CagA seropositive ( $41 \%$ vs $10 \%, P=$ 0.01 ). By logistic regression they identified CagA seropositivity, race, and positive screens for depression or somatization as variables independently associated with non-ulcer dyspepsia.

TREIBER et al. ${ }^{(25)}$ in a prospective cohort study, including 79 patients with peptic ulcer and 130 with functional dyspepsia, analyzed dyspeptic symptoms and potentially influencing factors before and up to 6 months following $H$. pylori eradication. They reported: "...the summary score of all dyspeptic symptoms decreased and during follow-up the proportion of symptom-free patients was higher in the group with peptic ulcers $(69.4 \%$ vs $40.9 \%, P<0.0001$ ) than with functional dyspepsia. Regardless of diagnosis, virulent strains of $H$. pylori were associated with a higher prevalence of epigastric pain before treatment". They also found that patients who consume a significant amount of alcohol or tobacco are more likely to show persistent symptoms after $H$. pylori eradication and for the same reason aspirin or NSAIDs should be replaced if possible. 
In our study the prevalence of gastritis $(72.5 \%)$ in patients with dyspepsia is in accordance with what was recently reported by NAYLOR et al. ${ }^{(15)}$ in dyspeptic patients from Japan $(60 \%)$, in comparison with dyspeptics from UK (47\%) - high versus low gastric cancer incidence areas. Among 53 Japanese subjects in whom they were able to culture and subtype $H$. pylori strains, they found almost $100 \%$ of s $1 \mathrm{~m} 1 / \mathrm{CagA}+$ genotype. In our sample, specifically for those having histology of moderate or severe gastritis $(27.5 \%)$, we also found a strong association with $\mathrm{H}$. pylori infection $(100 \%)$ and CagA virulence factor $(91 \%)$. Hence, considering that serology for anti-CagA antibody is not available in daily clinical practice and that gastric histology accurately reflects what happens with $H$. pylori infection, using histopathological criteria and treating only those with a moderate or higher grade of gastritis (the severity of which used to be correlated with the burden of $H$. pylori colonization and also associated with the presence of lymphoid follicles), we would be treating only around $30 \%$ of dyspeptic patients. This percentage is exactly what the literature has recently demonstrated concerning symptomatic benefit in FD after $H$. pylori eradication: only $11 \%$ to $38 \%$ will be symptom-free ${ }^{(1)}$. In other words, using gastric histology we could indirectly select for $H$. pylori treatment those with a high probability of being infected with virulent strains, which in turn would constitute the subset of patients having a much higher chance of achieving symptom improvement.

Before concluding: first, we did not actually evaluate the correlation between gastric histology and dyspeptic symptoms, but based on already available data linking cagA-positive strains to higher frequency and intensity of dyspeptic symptoms ${ }^{(25)}$ we speculate here that bad gastric histology might also be related to bad clinical expression. Second, although widely used "the updated Sydney System (Houston, 1994)" is somewhat cumbersome to be used in histopathological reports addressed to clinicians. Therefore, the Reporting System for Chronic Gastritis (Parma, 2005), proposed by RUGGE and GENTA ${ }^{(20)}$, in which the grade of inflammation and the stage of atrophy based on specimens from antrum and corpus are expressed in a scale from absence (zero) to severe (IV), seems to be the best way for clear and practical communication between pathologists and gastroenterologists. Third, the intention to biopsy on patients with dyspepsia should be explicit and that of the physician in charge of the case, since it is him who will have the opportunity to discuss and make therapeutic decisions based on clinical, endoscopic and histological data at the end of investigation.

\section{ACKNOWLEDGMENTS}

We are thankful to Dr. Julie Parsonnet, Dr. Atsuko Shibata, Dr. Douglas Passaro and Dr. Catherine Ley for their contributions with lab tests and invaluable advices. This project was financially supported by the Brazilian government (CAPES) and Stanford University (Department of Medicine and Health and Research Policy) in California, USA.

Arruda SMB, Forones NM, Jucá NT, Barros KSC. É a histologia gástrica um marcador útil na decisão de erradicar o Helicobacter pylori nos pacientes com dispepsia? Arq Gastroenterol. 2009;46(3):209-13.

RESUMO - Contexto - O benefício da terapia de erradicação do H. pylori como parte do tratamento da dispepsia funcional ainda é uma questão em aberto. Diferenças na distribuição geográfica, a ampla variabilidade genética e o fato de que a expressão clínica da infecção está fortemente relacionada com a virulência das cepas infectantes, são fatores que provavelmente guiam as controvérsias. Objetivo - Estudar a correlação entre histologia gástrica e sorologia para H. pylori em doentes com dispepsia. Métodos - Estudo descritivo-transversal com 40 pacientes consecutivos com sintomas dispépticos (28 mulheres e 12 homens, média de idade de 48,5 anos) e achado endoscópico de estômago normal, selecionados a partir da sala de endoscopia (Hospital das Clínicas da Universidade Federal de Pernambuco, Recife, PE.) entre março de 1998 e julho de 1999 . Todos foram submetidos a biopsias gástricas e testes sorológicos (anti-Hp e anti-CagA). As biopsias foram analisadas pelos métodos de $\mathrm{H}-\mathrm{E}$ e Giemsa e os achados de gastrite classificados de acordo com o Sistema Sydney atualizado. Resultados - A histologia dos 40 pacientes revelou que cerca de $1 / 4$ apresentava gastrite moderada $(25 \%)$ ou severa $(2,5 \%)$. Esse grupo também apresentava maior frequência de positividade anti-Hp (100\% vs $41 \% ; P=0,0005)$ e anti-CagA (91\% vs 58\%; P = 0,09) quando comparado com os casos com histologia normal $(27,5 \%)$ ou gastrite leve (45\%). Conclusão - Considerando que a endoscopia digestiva alta é parte da rotina de investigação da dispepsia funcional e que a sorologia anti-CagA não está disponível na prática clínica diária, através da histologia pode-se selecionar e aplicar terapia de erradicação do H. pylori apenas para os casos que muito provavelmente estão associados a cepas patogênicas de H. pylori (doentes com gastrite moderada ou severa) - cerca de 1/4 da presente amostra.

DESCRITORES - Dispepsia. Helicobacter pylori. Infecções por helicobacter. Antígenos de bactérias. Gastrite. 


\section{REFERENCES}

1. Anderson LA, Murphy SJ, Johnston BT, Watson RG, Ferguson HR, Bamford KB, Ghazy A, McCarron P, McGuigan J, Reynolds JV, Comber H, Murray LJ. Relationship between Helicobacter pylori infection and gastric atrophy and the stages of the oesophageal inflammation, metaplasia, adenocarcinoma sequence: results from the FINBAR case-control study. Gut. 2008;57:734-9.

2. Arista-Nasr J, Jiménez-Rosas F, Uribe-Uribe N, Herreta-Goepfert R, Lazos-Ochoa M. Pathological disorders of the gastric mucosa surrounding carcinomas and primary lymphomas. Am J Gastroenterol. 2001;96:1746-51.

3. Arruda SMB, Shibata A, Parsonnet J. Worldwide distribution of " $\mathrm{s}$ " and " $\mathrm{m}$ " vacA genotypes in $H$. pylori infected patients - a compilation of data. Gastroenterology. 2001;118(Suppl 2):A699.

4. Atherton JC. The clinical relevance of strain types of Helicobacter pylori. Gut. 1997;40:701-3.

5. Ching CK, Wong BC, Kwok E, Ong L, Covacci A, Lam SK. Prevalence of cagAbearing Helicobacter pylori strains detected by the anti-CagA assay in patients with peptic ulcer disease and in controls. Am J Gastroenterol. 1996;91:949-53.

6. Corley DA, Kubo A, Levin TR, Block G, Habel L, Zhao W, Leighton P, Rumore G, Quesenberry C, Buffer P, Parsonnet J. Helicobacter pylori infection and the risk of Barrett's oesophagus: a community-based study. Gut. 2008;57:727-33.

7. Dixon MF, Genta RM, Yardley JH, Correa P. Classification and grading of gastritis. The updated Sydney System. International Workshop on the Histopathology of Gastritis, Houston 1994. Am J Surg Pathol. 1996;20:1161-81.

8. Drossman DA. The functional gastrointestinal disorders and the Rome III process. Gastroenterology. 2006;130:1377-90.

9. Hua-Xiang Xia H, Talley NJ. Apoptosis in gastric epithelium induced by Helicobacter pylori infection: implications in gastric carcinogenesis. Am J Gastroenterol. 2001;96:16-26.

10. Jaakkimainen RL, Boyle E, Tudiver F. Is Helicobacter pylori associated with non-ulcer dyspepsia and will eradication improve symptoms? A meta-analysis. BMJ. 1999;319:1040-4

11. Laheij RJ, van Rossum LG, Verbeek AL, Jansen JB. Helicobacter pylori infection treatment of nonulcer dyspepsia: an analysis of meta-analyses. J Clin Gastroenterol. 2003;36:315-20.

12. Mazzoleni LE, Sander GB, Ott EA, Barros SG, Francesconi CF, Polanczyk CA, Wortmann AC, Theil AL, Fritscher LG, Rivero LF, Cartell A, Edelweiss MI, Uchôa DM, Prolla JC. Clinical outcomes of eradication of Helicobacter pylori on nonulcer dyspepsia in a population with a high prevalence of infection: results of a 12-month randomized, double blind, placebo-controlled study. Dig Dis Sci. 2006;51:89-98.
13. Mearin F, Pérez-Oliveras M, Perelló A, Vinyet J, Ibañez A, Coderch J, Perona M. Dyspepsia and irritable bowel syndrome after a Salmonella gastroenteritis outbreak: one-year follow-up cohort study. Gastroenterology. 2005;129:98-104

14. Moayyedi P, Soo S, Deeks J, B Delaney, Harris A, Innes M, Oakes R, Wilson S, Roalfe A, Bennett C, Forman D. Eradication of Helicobacter pylori for non-ulcer dyspepsia. Cochrane Database Syst Rev. 2005;1:CD002096.

15. Naylor GM, Gotoda T, Dixon M, Shimoda T, Gatta L, Owen R, Tompkins D, Axon A. Why does Japan have a high incidence of gastric cancer? Comparison of gastritis between UK and Japanese patients. Gut. 2006;55:1545-52.

16. Nelson D, Murdoch M, Sandozi IK, Dalmasso AP, Crabtree JE, Ho SB. Dyspepsia is associated with CagA-positive Helicobacter pylori. Am J Gastroenterol. 2000;91:3412-7.

17. Nguyen TN, Barkun AN, Fallone CA. Host determinants of Helicobacter pylori infection and its clinical outcome. Helicobacter. 1999:4:185-97.

18. Queiroz DMM, Oliveira CA, Rocha GA, Oliveira AMR, Cabral MMDA, Nogueira AMMF. cagA-Positive $H$. pylori and risk for developing gastroesophageal reflux disease [abstract]. Gut. 1999;45(Suppl):A81. [abstract 11/02].

19. Rokkas T, Ladas S, Liatsos C, Petridou E, Papatheodorou G, Theocharis S, Karameris A, Raptis S. Relationship of Helicobacter pylori CagA status to gastric cell proliferation and apoptosis. Dig Dis Sci. 1999;44:487-93.

20. Rugge M, Genta RM. Staging and grading of chronic gastritis. Hum Pathol 2005;36:228-33.

21. Saad RJ, Chey WD. Current and emerging therapies for functional dyspepsia [review article]. Aliment Pharmacol Ther. 2006;24:475-92.

22. Spiller RC. Inflammation as a basis for functional GI disorders. Best Pract Res Clin Gastroenterol. 2004;18:641-61.

23. Tack J, Demedts I, Dehondt G, Caenepeel P, Fischler B, Zandecki M, Janssens J Clinical and pathophysiological characteristics of acute-onset functional dyspepsia. Gastroenterology. 2002;122:1738-47.

24. Talley NJ, Colin-Jones D, Kock KJ, Kock M, Nyrén O, Stanghellini V. Functiona dyspepsia: a classification with guidelines for diagnoses and management. Gastroenterol Int. 1991;4:145-60.

25. Treiber G, Schwabe M, Ammon S, Walker S, Klotz U, Malfertheiner P. Dyspeptic symptoms associated with Helicobacter pylori infection are influenced by strain and host specific factors. Aliment Pharmacol Ther. 2004;19:219-31.

26. Van Doorn LJ, Figueiredo C, Megraud F, Pena S, Midolo P, Queiroz DMM, Carneiro F, Vanderborth B, Pegado MGF, Sanna R, de Boer W, Schneeberger PM, Correa P, Enders KWNG, Atherton JC, Blaser MJ, Quint WGV. Geographic distribution of vacA allelic types of Helicobacter pylori. Gastroenterology. 1999; 116:823-30.

Recebido em 17/9/2008. Aprovado em 16/2/2009. 